Check for updates

Plymouth

Cite this as: $B M J 2022 ; 376: 0133$ http://dx.doi.org/10.1136/bmj.0133 Published: 18 January 2022

\section{Covid-19: Brazil sees omicron cases soar but data blackout obscures true impact}

Luke Taylor

The omicron variant of SARS-CoV-2 has led to a spike in infections in Brazil with a rolling average of 69010 new daily cases reported on 14 January, up from 22 626 a week earlier. But the true increase is likely to be significantly higher because of insufficient testing and failing public health databases, said public health experts.

The impact of the more infectious omicron variant on Latin America has come later than in Europe and North America but is currently driving a regional surge. ${ }^{1}$

More than $95 \%$ of coronaviruses sequenced by some Brazilian private health services and cities are the new variant, said Gerson Salvador, an infectious disease specialist and doctor at the University of São Paulo. However, the impact of omicron has been obscured by data blackspots because an attempt to hack Brazil's Health Ministry for ransom last month has left several databases offline, limiting the government's ability to collect data from state health authorities. ${ }^{2}$

"We have been experiencing a blackout since last month and don't know from official data the exact numbers of covid-19 infections in Brazil," said Salvador. A shortage of tests in the biggest cities is also leading to under-reporting. "The number of known cases is growing exponentially, but the official data we get is greatly underestimating the number of cases," added Salvador.

César Eduardo Fernandes, head of the Brazilian Medical Association, has told Reuters that the rise in hospital admissions is a concern, as is a tripling of staff absences in the four weeks since the omicron wave hit. "It is possible some services will collapse," he said. ${ }^{2}$

On 14 January a physicians' union in Sao Paulo threatened to strike in major public clinics if overworked doctors were not backed by more staff.

\section{Vaccinations}

Although the increase in infections is steep, its impact so far does not compare to previous waves of infections, which led to hospitals collapsing and the need to dig mass graves.

The acceleration of Brazil's vaccination campaign greatly reduced the number of hospital admissions and deaths in the second half of 2021, and $67 \%$ of Brazilians are now fully vaccinated. "We are seeing an explosion of omicron cases but proportionately fewer deaths thanks to vaccines," said Salvador.

A rolling average of 154 daily deaths was reported on 16 January, down from more than 3000 daily fatalities reported in April 2021, when infections peaked.
Renata Pieratti Bueno's intensive care clinic at a major São Paulo public hospital had not seen covid-19 patients for months but has seen admissions return in the past week. "Yet so far [covid-19] does not seem to be exploding like it did in other waves," she said, adding that the vast majority of patients were elderly or had comorbidities, unlike previous waves, which were less age discriminating.

President Jair Bolsonaro has downplayed the threat of omicron and ruled out lockdowns as a possible government response. ${ }^{3}$

"Herd immunity is a reality," he said on 12 January. "A person immunised with the virus has a lot more antibodies than a vaccinated person.” Bolsonaro also contested the first Brazilian death from omicron, which was reported in the state of Goias, attributing the fatality to other issues.

Taylor L. Covid-19: Omicron drives weekly record high in global infections. BMJ 2022;376:066. doi: 10.1136/bmj.066 pmid: 35017144

2 Fonseca P, Simões E. Brazil reels as COVID-19 cases soar; hospitals, economy under pressure. Reuters. 14 Jan 2022. https://www.reuters.com/world/americas/brazil-reels-omicron-spreadsweighing-hospitals-economy-2022-01-14/

3 Brazil's Bolsonaro downplays Omicron. France24. 12 Jan 2022. https://www.france24.com/en/live-news/20220112-brazil-s-bolsonarodownplays-omicron

This article is made freely available for personal use in accordance with BMJ's website terms and conditions for the duration of the covid-19 pandemic or until otherwise determined by BMJ. You may download and print the article for any lawful, non-commercial purpose (including text and data mining) provided that all copyright notices and trade marks are retained. 